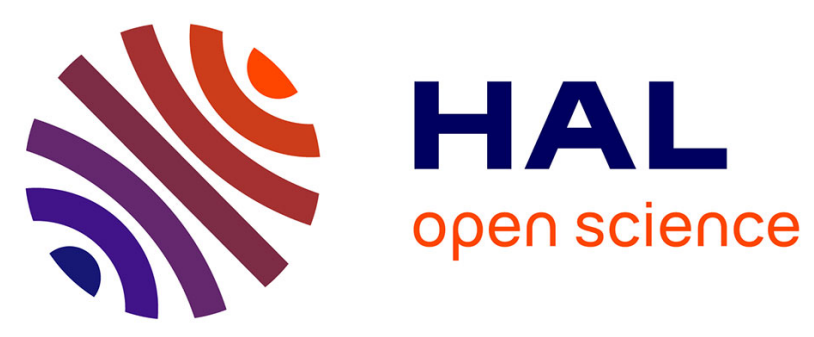

\title{
Reinstatement of Ectocarpus crouaniorum Thuret in Le Jolis as a third common species of Ectocarpus (Ectocarpales, Phaeophyceae) in Western Europe, and its phenology at Roscoff, Brittany
}

Akira F Peters, Serinde J van Wijk, Ga Youn Cho, Delphine Scornet, Takeaki Hanyuda, Hiroshi Kawai, Declan Schroeder, J. Mark Cock, Sung Min Boo

\section{To cite this version:}

Akira F Peters, Serinde J van Wijk, Ga Youn Cho, Delphine Scornet, Takeaki Hanyuda, et al.. Reinstatement of Ectocarpus crouaniorum Thuret in Le Jolis as a third common species of Ectocarpus (Ectocarpales, Phaeophyceae) in Western Europe, and its phenology at Roscoff, Brittany. Phycological Research, 2010, 58 (3), pp.157 - 170. 10.1111/j.1440-1835.2010.00574.x . hal-01925565

HAL Id: hal-01925565

https://hal-univ-rennes1.archives-ouvertes.fr/hal-01925565

Submitted on 18 Dec 2020

HAL is a multi-disciplinary open access archive for the deposit and dissemination of scientific research documents, whether they are published or not. The documents may come from teaching and research institutions in France or abroad, or from public or private research centers.
L'archive ouverte pluridisciplinaire HAL, est destinée au dépôt et à la diffusion de documents scientifiques de niveau recherche, publiés ou non, émanant des établissements d'enseignement et de recherche français ou étrangers, des laboratoires publics ou privés. 
Version of 301109 - revised version sent to associate editor; in total 7400 words

\section{Title}

Reinstatement of E. crouaniorum Thuret in Le Jolis as a third common

species of Ectocarpus (Ectocarpales, Phaeophyceae) in western Europe,

\section{and its phenology at Roscoff, Brittany}

Akira F. Peters, ${ }^{1,2,3^{*}}$ Serinde J. van Wijk, ${ }^{1 \dagger}$ Ga Youn Cho, ${ }^{4 *}$ Delphine Scornet, ${ }^{2}$ Takeaki

Hanyuda, ${ }^{5}$ Hiroshi Kawai, ${ }^{5}$ Declan C. Schroeder, ${ }^{3}$ J. Mark Cock ${ }^{2}$ and Sung Min Boo, ${ }^{4}$

${ }^{1}$ UMR7139, Station Biologique, Centre National de la Recherche Scientifique et Université

Pierre \& Marie Curie Paris VI, Place Georges Teissier, 29682 Roscoff cedex, France, ${ }^{2}$ Bezhin

Rosko, 28 route de Perharidy, 29680 Roscoff, France, ${ }^{3}$ Marine Biological Association, Citadel

Hill, Plymouth PL1 2PB, UK, ${ }^{4}$ Department of Biology, Chungnam National University, Daejeon

305-764, Korea, ${ }^{5}$ Kobe University Research Center for Inland Seas, Rokkodai, Kobe 657-8501, Japan

Running title: Reinstatement of Ectocarpus crouaniorum [39 characters/40 permitted]

*To whom correspondence should be addressed.

Email: akirapeters@gmail.com

Communicating editor: $\mathrm{xxxxx}$

Present addresses: $\uparrow$ Molecular Ecology and Fisheries Genetics Laboratory, Biological Sciences, Bangor University, Deiniol Road, Bangor, Gwynedd LL57 2UW, UK, 
+ Division of Non-vascular Plants, National Institute of Biological Resources, Incheon 404-708, Korea 


\section{SUMMARY}

Based on morphological characters, cross-fertility and molecular systematics two species are currently recognised in the ubiquitous temperate brown algal genus Ectocarpus: the type species E. siliculosus (Dillwyn) Lyngbye and E. fasciculatus Harvey. We studied diversity, cross-fertility and ecology of Ectocarpus in megatidal areas in NW France (Western Europe) and propose to reinstate a third species, E. crouaniorum Thuret in Le Jolis. Genotyping of 67 individuals from five localities, including the type locality of E. crouaniorum, using ITS1 length as a marker, showed that the three species co-occurred whenever the habitat was suitable. Our survey also revealed a single putative field hybrid between E. crouaniorum and E. siliculosus, and a single individual of a further Ectocarpus genotype. In laboratory experiments, E. crouaniorum was crossed with E. siliculosus and E. fasciculatus. In twelve of 13 crosses, the zygotes did not develop (postzygotic sterility); in one experiment a viable hybrid was produced after crossing a female E. crouaniorum with a male E. siliculosus, but this hybrid was unable to form meiospores. Phylogenetic analysis of five molecular markers from the nuclear, mitochondrial and plastid genomes (in total $1818 \mathrm{bp}$ ) confirmed genetic separation of the three species. Ecologically, E. crouaniorum was confined to high intertidal pools and run-offs, where the gametophyte was common from spring to summer. Another characeristic was that it usually occurred as an epiphyte of up to $12 \mathrm{~cm}$ in length on erect thalli of Scytosiphon lomentaria. Sporophytes of E. crouaniorum were found all year long; they were $<3 \mathrm{~cm}$ in size or microscopic and were epilithic in the same habitat. E. crouaniorum thus shows a marked heteromorphism between the generations. The presence of a third species of Ectocarpus in Western Europe suggests that species diversity in this genus is larger than recognised during the last 40 years. [285 words/300 permitted] 
Key words: Ectocarpus, taxonomy, phenology, phylogeny, biological species, hybrid, postzygotic sterility, genotyping, ITS1 length 


\section{INTRODUCTION}

Ectocarpus is a brown algal genus with a long research history (Peters et al. 2004a; Coelho et al. 2007; Charrier et al. 2008) and includes the first macroalga for which the genome has been entirely sequenced (www.genoscope.cns.fr/spip/Ectocarpus-siliculosus,740.html). However, species diversity within the genus is not yet resolved. Based on the number of taxa described, Ectocarpus is one of the most species-rich genera of the Phaeophyceae: AlgaeBase lists 410 species of which 101 are flagged as currently accepted taxonomically (Guiry and Guiry 2009). In the $19^{\text {th }}$ and the first half of the $20^{\text {th }}$ century, brown algae with uniseriate branched filaments were generally classified in Ectocarpus, leading to a proliferation of new species; currently two morphological characters are being used to separate members of the genus Ectocarpus sensu stricto from other small brown algae. Firstly, plastids are extended ribbons bearing pedunculated pyrenoids, and are not discoid as in the majority of genera with similar thalli, such as Hincksia, Pylaiella, Acinetospora and Feldmannia (Kornmann and Sahling 1977; Peters and Ramírez 2001). Secondly, Ectocarpus has no genuine phaeophycean hairs, which are present in the sister genus, Kuckuckia (Hamel 1939; Kuckuck 1958; Pedersen 1989).

Species distinctions within Ectocarpus sensu stricto have differed greatly among investigators; morphological, biological and phylogenetic species concepts and chemotaxonomy have been employed to investigate its diversity. The most comprehensive morphological studies were done on European representatives. A classification of five species into two major groups (section siliculosi and section fasciculati) based on branching pattern and sporangium shape was proposed by Hamel (1931-39). Cardinal (1964) recognised four species, with seven varieties in E. siliculosus and three varieties in E. fasciculatus. Russell $(1966,1967)$ showed that sporangium morphology, formerly used to distinguish species in the siliculosus complex, was not informative. 
However, branching pattern consistently revealed a difference between thalli with conspicuous main axes and thinner, often fasciculate, laterals (E. fasciculatus) and thalli showing subdichotomous branching (E. siliculosus). Russell's proposal for a classification of European Ectocarpus in merely two species was generally accepted and was extended to all Ectocarpus world-wide. However, some authors continued to recognise additional species, such as E. constanciae Hariot, E. acutus Setchell et Gardner and E. penicillatus C. Agardh (Ricker 1987; Santelices 1989; Kim and Lee 1992; Stegenga et al. 1997).

Both Ectocarpus siliculosus and E. fasciculatus show an alternation of two generations. In culture studies Kornmann (1956), Müller (1964, 1966, 1967, 1972) and Kornmann and Sahling (1977) showed that the generations might differ in morphology, which to some extent would help explain the morphological diversity of field material noticed in previous studies. However, little is known about the distribution and phenology of the different generations in the field. Crossing experiments (Müller and Eichenberger 1995) showed that there is intersterility between E. siliculosus and E. fasciculatus occurring sympatrically in Brittany: although male gametes of E. fasciculatus were able to fuse with female gametes of E. siliculosus, however, the resulting zygotes did not develop beyond a two-celled stage (post-zygotic intersterility). Gamete fusions were not observed in the reciprocal gamete combination (pre-zygotic intersterility). Within E. siliculosus, which is more widely distributed than E. fasciculatus, strains from different geographical origins were often but not always cross-fertile at the level of plasmogamy. However, post-zygotic sterility barriers were frequent: hybrids, particularly between isolates from different hemispheres, showed reduced development or normal growth but inhibition of meiosis (Müller 1977, 1979, 1988; Stache 1989, 1993); there were also cases of pre-zygotic reproductive isolation of E. siliculosus populations from NE America (Müller 1976; cross-fertility data reviewed in Stache-Crain et al. 1997). Müller and Kawai (1991) concluded that E. siliculosus is a 
single species with a world-wide distribution consisting of many geographically separated populations that show full or slightly reduced interbreeding patterns.

Phylogeographic analysis of nuclear ribosomal internal transcribed spacer (ITS) and plastid Rubisco spacer sequences of 43 strains of Ectocarpus and seven of Kuckuckia, which had been isolated by Dieter Müller on all continents except Antarctica, supported a principal division of Ectocarpus into two major clades (Stache-Crain et al. 1997). This appeared to corroborate the recognition of only E. siliculosus and E. fasciculatus. However, cases of reproductive isolation between strains within the clade of E. siliculosus are documented. Moreover, sub-clades separated by considerable genetic distances (partly unalignable ITS sequences) suggest that in reality more species of Ectocarpus may exist.

The coasts of Brittany in Western Europe, situated at the border of cold and warm-temperate biogeographic regions, are characterised by large tides and a mild stenotherm climate, which permit the presence of a diverse macroalgal flora (van den Hoek 1975). It was thus suitable for testing the hypothesis that only two species of Ectocarpus exist. For our study we collected and genotyped 67 isolates of Ectocarpus from 5 localities, crossed and sequenced a few of them and found evidence supporting recognition of a third species of Ectocarpus which we found to best agree with E. crouaniorum, the name henceforth used in this paper. 


\section{MATERIALS AND METHODS \\ Field observations}

A total of seven intertidal and upper subtidal habitats in North-Western France at four localities in Brittany and one in Normandy (Fig. 1) were examined for the presence of Ectocarpus. At the main study site, which lies close to the Roscoff Marine Station, observations were made repeatedly, the others were visited 1-3 times (Table 1). Thalli were placed in separate plastic bags during collection and processed immediately after transport to the laboratory.

\section{Strain isolation and culturing}

Replicate isolates of Ectocarpus were made from January 2002 onwards. Cultivation was done in autoclaved sea water from Roscoff, adding 10ml Provasoli enrichment (prepared according to Starr and Zeikus 1993) per litre, in non-aerated cultures at $14 \pm 1^{\circ} \mathrm{C}$ in white light of $10-30 \mu \mathrm{mol}$ photons $\mathrm{m}^{-2} \mathrm{~s}^{-1}$ and a daylength of 10:14h LD. For isolation, minute fragments of each field thallus were inoculated in four replicates in 2-3 ml culture medium with or without $6 \mathrm{mg} / \mathrm{GeO}_{2}$. After two to six weeks, the inoculates were microscopically examined for the presence of contaminants and for each sample an unialgal culture without eukaryotic contamination was transferred to culture medium without $\mathrm{GeO}_{2}$.

Strain designations beginning with "CCAP1310/" are from the Culture Collection of Algae and Protozoa, Oban, Scotland, numbers preceded by "Ec" are isolates housed in the macroalgal culture collection at Roscoff maintained by the first author.

\section{Sexual crosses and raising of zygotes}

Experiments on cross-fertility were undertaken in 2003-2005 using field thalli or strains from stock cultures. Gametophytes of E. crouaniorum came from a population in the upper intertidal at 
Site 1 . They were field thalli or they developed in culture from spores from unilocular sporangia of sporophytes. None of our new isolates of E. siliculosus was sexual; therefore we used reference gametophyte strains from stock cultures. They were CCAP1310/330 (female) and CCAP1310/329 (male); these had been obtained from meiospores on a sporophyte (CCAP1310/331) resulting from a cross of a female strain from Roscoff (CCAP1310/178) with a male strain from Naples, Italy (CCAP1310/131), both isolated previously by Dieter Müller. The strains CCAP1310/178 and CCAP1310/131 are genetically similar (Peters et al. 2004b, as "Ros $\mathrm{f}^{\prime \prime}$ and "Na m") and belong to lineage 1a of E. siliculosus in Stache-Crain et al. (1997). Gametophytes of E. fasciculatus were obtained from a sporophyte growing endophytically in Saccharina latissima (Linnaeus) Lane, Mayes, Druehl et Saunders which was isolated by author AFP at Site 1 on 20 January 2002. The specific identity of the E. fasciculatus reference strains was confirmed by determination of ITS1 length (see below). The fourth Ectocarpus genotype encountered (see Results) was not involved in crossing experiments because we did not obtain gametophytes from it.

Zygotes were produced by combining fertile gametophyte fragments in hanging-drop preparations in which gamete fusions could be observed under the microscope. Even without witnessing plasmogamy, putative zygotes were distinguishable from settled gametes by their double inventory of plastids and stigmata. Incompletely cleaved zoids ("Doppelschwärmer") may resemble zygotes, but they occur only rarely among gametes (Müller 1967: $\leq 0.2 \%$ ). To raise zygotes, we chose cells in preparations containing numerous cells with double inventory of organelles. This made an erroneous selection of a "Doppelschwärmer" unlikely. Zygotes were raised and isolated as described previously (Peters et al. 2004b).

\section{Molecular methods}


Different isolates of Ectocarpus show significantly differing ITS1 lengths, due to large indels in the first part of ITS1 (Stache-Crain et al. 1997). Length of ITS1 was therefore suitable for genotyping. DNA was extracted from culture material as described in Peters et al. (2004b), followed by PCR. Cultures were preferred over field material because in the latter a sample may contain more than a single individual. ITS1 length genotyping was performed twice for each strain. We subsequently sequenced (method described in Peters et al. 2004b) nuclear and cytoplasmic markers (Table 2) in 1-3 different individuals of each ITS1 length genotype. Apart from being a standard procedure in our laboratory to facilitate sequencing with universal primers, cloning served to avoid problems with heterogeneous DNA, which may be present in nuclear ribosomal DNA of diploid samples. Sequences were also generated in reference strains utilised for phylogenetic analyses (Table 2). Primer information is provided in Table 3.

\section{Sequence comparisons and phylogenetic analyses}

Sequences obtained were compared to Ectocarpus sequences in GenBank using blastn (Altschul et al. 1997) and to sequences of the genome-sequenced strain (Cock et al. unpublished; Le Corguillé et al. 2010).

To avoid erroneous aligning, most indel-rich parts of the ITS regions and the entire spacer between rps 14 and atp 8 were excluded before executing phylogenetic analyses. The alignment consisted of ITS1 (187bp) and ITS2 (163 bp), Rubisco spacer plus adjacent sectors of $r b c \mathrm{~L}$ and $r b c \mathrm{~S}$ (515 bp), cox3 (665 bp) and rps14 (288 bp). Our taxon sampling comprised 15 strains including ten Ectocarpus from France, one each from the Isle of Man, New Zealand and Peru, and two strains of Kuckuckia used as an outgroup. Phylogenetic trees were calculated according to maximum parsimony (MP), neighbor joining (NJ; Kimura-2-parameter genetic distance), maximum likelihood (ML) and Bayesian analyses. The best model for maximum likelihood analysis was traced under the Akaike Information criterion (AIC) using ModelTest 3.08b (Posada 
and Crandall 1998). The ML analysis was performed under the GTR $+\mathrm{I}+\Gamma$ model using PAUP* v4.0b10 (Swofford 2002). The analysis was performed by heuristic searches with 100 random sequence addition, tree bisection-reconnection (TBR) branch swapping, and MulTrees options. Bootstrap analysis was made for 1,000 replicates with 10 random sequence additions. Other options were same as with the ML tree search. MP and NJ analyses were also made using PAUP. Bayesian analysis was performed using the GTR $+\mathrm{I}+\Gamma$ model for the combined data using MrBayes v. 3.1.2 (Huelsenbeck and Ronquist 2001). The analysis was conducted from a random starting tree, and the program was set to perform two independent runs with four chains of Markov chain Monte Carlo iterations simultaneously for 2,000,000 generations with trees sampled every $100^{\text {th }}$ generation, respectively. We harvested trees after 500,000 generations after the average standard deviation of split frequencies reached a value below 0.005. A total of 15,000 trees were combined to produce a $50 \%$ majority rule tree. 


\section{RESULTS}

\section{Field presence}

Around Roscoff, Ectocarpus occurred all year round from high intertidal pools to the upper subtidal. However, in the high intertidal macroscopic thalli were only observed in spring (end of March to end of June); in the mid intertidal thalli were also found later in the year and in the low intertidal and upper subtidal, Ectocarpus could nearly always be encountered. Thalli were epiphytic on a variety of marine macrophytes. In the high intertidal the preferred substratum were the erect phase of Scytosiphon (Fig. 2) or occasionally thalli of Asperococcus, in the mid intertidal mainly Ulva, Porphyra and Sargassum (Fig. 3), and in the low intertidal and subtidal Himanthalia, Laminaria, Saccharina, Saccorhiza, Gracilaria and Zostera marina Linnaeus (Fig. 4). Macroscopic thalli were rarely found growing on rock, stones, gravel or maerl. Contrary to Pylaiella littoralis (Linnaeus) Kjellman, which was common at the same sites, often epiphytic on Fucus and regularly emersed at low tide, Ectocarpus apparently required constant submersion and in the mid and upper intertidal it was confined to pools or run-offs.

\section{Genotyping}

Diagnostic PCR of in total 67 strains revealed four different ITS1 lengths (Fig. 5). Thalli from Sites 1-3 (28 samples) had three different ITS1 lengths. ITS1 of individuals from the high intertidal, which were in the course of the study identified as E. crouaniorum, was about $150 \mathrm{bp}$ longer than that of E. siliculosus from the mid intertidal and $430 \mathrm{bp}$ longer than that of E. fasciculatus from the upper subtidal. The same three ITS1 lengths and the same distribution across the intertidal were obtained in thalli collected at Site 5 (22 samples; Fig. 6), except that a thallus epiphytic on Bifurcaria in the lower intertidal also belonged to E. crouaniorum. At Site 4, 
where high intertidal pools were absent, only genotypes of E. siliculosus and E. fasciculatus were present (6 samples). At Site 6, which in contrast to all other sites has strong wave exposure, we collected only in the intertidal (4 samples) and obtained only E. crouaniorum, both from high and mid intertidal pools. Sampling at Site 7 (7 samples) was also done only in the intertidal and there, we found E. crouaniorum, E. siliculosus, and in addition a thallus with an ITS1 length ca. $70 \mathrm{bp}$ shorter than in E. siliculosus.

A single field isolate from Site 1 showed a double band with the sizes of E. crouaniorum and E. siliculosus. The same bands were obtained in the hybrid produced in the laboratory described below (Fig. 7).

\section{Crossing studies}

Gamete fusions were observed in material from plurilocular field thalli of E. crouaniorum (Fig. 8) when fragments from male and female thalli were placed in the same preparation. Several of the thalli were genotyped as described above. In interspecific crosses, female and male gametes from such thalli underwent plasmogamy with male and female gametes of E. siliculosus, respectively (Table 4). In crosses with E. fasciculatus, zygotes were formed between female gametes of E. crouaniorum and male gametes of E. fasciculatus but not in the reciprocal combination. Control experiments with material from the same gametophytes of E. crouaniorum showed that the male gametes that failed to fuse with female gametes of E. fasciculatus were capable of fusing with conspecific gametes.

The development of 292 zygotes was followed (Table 4). Whereas zygotes from intraspecific crosses developed normally (not shown), those from interspecific crosses usually died within 3-4 days after plasmogamy, before having undergone the first cell division. In the same preparations, germlings from settled gametes developed into parthenogenetic sporophytes (Fig. 9). In one 
experiment of the combination female E. crouaniorum $\mathrm{x}$ male E. siliculosus, however, all nine selected zygotes developed normally. One of the thalli was raised to maturity. It formed unilocular sporangium mother cells (the site of meiosis in normal sporophytes), which were characteristically dome-shaped to ovoid (Fig. 10). In the hybrid thallus, unilocular sporangia did not develop beyond this early stage whereas in sporophytes of $E$. crouaniorum they increased in size and finally released meiospores (Figs 11-13).

\section{Sequence comparisons}

For the three Ectocarpus species from Brittany and the genome-sequenced strain the entire SSU gene (1802 bp), $1071 \mathrm{bp}$ of 5'-LSU and $r b c \mathrm{~L}(1467 \mathrm{bp}$ ) were similar, and the 5.8S gene (161 bp) was identical. Three full-length SSU and one partial LSU sequences of Ectocarpus in GenBank (L43062, AY307398, AY307399, EF990201) as well as the same genes in the genome-sequenced strain were also similar (between 3 and 10 substitutions) but the "historical" E. siliculosus $r b c \mathrm{~L}$ sequence (X52503, Valentin and Zetsche 1990) was about twice as distant.

ITS 1 and 2, Rubisco spacer, cox3, rps 14+spacer were generally near-identical in isolates of the same species; however, the two isolates of E. fasciculatus showed some differences in the second half of ITS1 and in the rps 14-atp 8 spacer. Across different species, Rubisco spacer, cox3 and rps 14 aligned perfectly but in the ITS regions as well as in the rps14-atp 8 spacer, conserved regions were interrupted by unalignable sectors. The first part of ITS1 was particularly variable, comprising the large indels that are responsible for the differences in ITS1 length in different genotypes.

A blastn search using ITS1 of E. crouaniorum as a query showed that highly similar sequences ( $98 \%$ identity) had been found previously in isolates from the Isle of Man (accession U38771;

CCAP1310/144) and the Aran Islands (U38770; CCAP1310/291). ITS1 of our isolates of 
E. siliculosus and E. fasciculatus agreed with known sequences of strains of the two species (e.g. U38760; CCAP1310/177; 97\% and U38824; CCAP1310/12; 96\% identity, respectively). ITS1 of the isolate from Site 7, with an ITS1 length between E. siliculosus and E. fasciculatus, matched ITS1 of a previous isolate from Copenhagen (U38777; CCAP1310/100; 97\% identity).

\section{Phylogenetic analyses}

Concatenated sequences from the five markers gave an alignment of $1818 \mathrm{bp}$, of which 302 were variable, thereof 211 parsimony-informative. All phylogenetic analyses provided essentially the same tree (Fig. 14). Ectocarpus was divided into two clades. The larger one contained genuine E. siliculosus and E. crouaniorum in two well separated sub-clades. The genome-sequenced Ectocarpus from Peru clustered with E. siliculosus ( $\geq 93 \%$ bootstrap support) but the strain from New Zealand formed an independent lineage. The other clade contained E. fasciculatus and the unnamed isolate from Cherbourg. Analyses using data from single markers (results not shown) differed in the position of the strains from New Zealand and Peru but always grouped the samples of E. crouaniorum together, separated from the branch containing genuine E. siliculosus.

\section{Phenology and morphology}

Thalli of E. crouaniorum on Scytosiphon at Site 1 were gametophytes as they did not bear unilocular sporangia and on several occasions the zoids released from their plurilocular organs behaved as gametes (see above). They appeared in early spring and lasted until early to mid summer; during these 3-4 months fertile thalli were always easy to find (Table 5). Field sporophytes were only observed at Sites 1 and 3. In March and April 2004 and 2005, two groups of small thalli of up to $30 \mathrm{~mm}$ height were collected in high intertidal run-offs. They grew on a dead Patella shell and on old wood and bore both unilocular and plurilocular sporangia. An 
individual from each group was genotyped and sequenced and identified as E. crouaniorum. These two findings suggested that in E. crouaniorum, the sporophyte might differ morphologically from the gametophyte. In 2007 we started to screen the substratum around the main E. crouaniorum population at Site 1 for minute field thalli. They were thereafter observed at seven occasions, growing on dead mollusc shells or stones. They were microscopic or small thalli rarely attaining more than $10 \mathrm{~mm}$ in size (Figs 15, 16). Unilocular sporangia (Fig. 13) were only observed in March and April, accompanied by plurilocular sporangia (Fig. 16), which were the only reproductive organs in summer and winter (Table 5). Like gametophytes, sporophytes were permanently submerged. Two isolates made from microscopic thalli on 15 April 07 and 28 June 07 were genotyped; the first was again E. crouaniorum but the second showed a double band with the sizes of E. crouaniorum and E. siliculosus (Fig. 7).

Overall thallus size and number of stalk cells of plurilocular organs were measured in E. crouaniorum gametophytes and E. siliculosus thalli at Site 1. Individuals of E. crouaniorum were up to $12 \mathrm{~cm}$ long, but usually much smaller (mean $25 \pm 25 \mathrm{~mm} \mathrm{SD;}=24$ ), and often they were already fertile at a size of 10-20 mm. E. siliculosus thalli were significantly larger (mean $74 \pm 40 \mathrm{~mm}$ SD; $n=29$; t-test: $p=0.0001)$. Stalk cells were counted at the base of 135 plurilocs in five thalli of E. crouaniorum and in 60 plurilocs in two thalli of E. siliculosus. The means (3.19 and 3.75, respectively) were insignificantly different (t-test: $p=0.2)$ 


\section{DISCUSSION}

The present study demonstrates that three biological species of Ectocarpus occur sympatrically in Brittany. Pre- or post-zygotic incompatibility maintains their genetic separation. Differences in the DNA sequences of five genetic markers (nucleus: ITS1 and ITS2; plastid: $r b c$ L+Rubisco spacer; mitochondrion: cox3, rps14-atp8 spacer) independently confirmed that there is no gene flow among the three species. Two of the species had been distinguished previously, based on morphology and lipid composition: E. siliculosus with pseudodichotomous branching and not containing diacylglycerylhydroxymethyltrimethyl- $\beta$-alanine (DGTA), and E. fasciculatus with prominent principal filaments and thinner, often fasciculate laterals, containing DGTA (Müller and Eichenberger 1995). These species were confirmed in our study; they were found in Brittany from mid-intertidal pools to the subtidal (E. siliculosus) or from the lowermost intertidal to the subtidal (E. fasciculatus). The habitat on Scytosiphon in high intertidal pools was the key to finding the appropriate name for the third species. Thuret (in Le Jolis 1863) described E. crouaniorum from exactly this habitat and we collected specimens of it both at the type locality and at the site of a historical record (Crouan and Crouan 1852, as E. fenestratus Crouan). In the original description, the name was E. crouani but as it honoured the two brothers Crouan it has to be corrected to the Latin genitive plural (Ergün Taskin, pers. comm.). E. crouaniorum had still been recognised as a distinct species by Hamel (1931-39), before it was considered a variety or growth phase of E. siliculosus by later authors (e.g. Cardinal 1964, Russell 1966, Gallardo 1992).

Our observation that thalli of E. crouaniorum growing on Scytosiphon are dioecious gametophytes correlates with the fact that no unilocular sporangia have been described in this species (Cardinal 1964). The corresponding sporophytes were morphologically different, small 
thalli with a maximum size of $30 \mathrm{~mm}$. Microscopic sporophytes were frequent on stones and shells throughout the year in the zone where the gametophytes occurred in spring. Meiosporangia were only found in spring, which would coincide with the appearance of the gametophytes in that season; in the other seasons, the sporophytes produced mitosporangia to replicate the same generation. E. crouaniorum appears to be even more strongly heteromorphic than other species of Ectocarpus studied so far. Judging from laboratory cultures, other species of Ectocarpus may also possess dissimilar generations; the gametophytes are ephemeral erect thalli, whereas the sporophytes are persistent and raise on an initially prostrate base (Müller 1964, 1966, 1972; Peters et al. 2008). In E. siliculosus, however, the sporophyte may form large thalli as well. There are a few reports on the presence of fertile gametophytes of E. siliculosus in nature (Berthold 1881; Kuckuck 1912; Papenfuss 1935) but the present field observations appear to provide the first hard data on the phenology of both generations of any Ectocarpus.

Ectocarpus crouaniorum is easily accessible on the shore and may have been described earlier, e.g. by Kützing $(1843,1845,1849,1855,1860)$ who described 56 species of Ectocarpus; however, the types of these taxa are considered to be lost (Prud'homme van Reine and den Hartog 1973) and the descriptions and original figures are usually not informative enough, in particular concerning ecological data. Among the taxa described before 1863 we have not found any that would match the species as well as Thuret's E. crouaniorum. We have neither found any older description with which the small sporophyte of E. crouaniorum would agree. Plurilocular sporangia in E. subulatus Kützing (incl. E. amphibius Harvey), which was also described from a high intertidal habitat, are significantly longer than the plurilocular organs of E. crouaniorum. We consider it most appropriate to propose reinstatement of E. crouaniorum for the entity in the high intertidal. 
Morphological differences between E. crouaniorum and E. siliculosus are minute. Le Jolis (1863) and Hamel (1931-1939) mentioned that plurilocular organs in lower parts of E. crouaniorum are often borne on long pedicels. However, our count of stalk cells in individuals of both taxa from the same site did not reveal significant differences. Overall size, in contrast, may be informative as the gametophytes of E. crouaniorum were despite some overlap significantly smaller than the thalli of E. siliculosus.

Taking habitat and season into consideration may also help to distinguish the two species, at least on sheltered megatidal shores in Brittany where the different zones are well separated. The conspicuous E. crouaniorum gametophytes were usually confined to upper intertidal pools where they were found on Scytosiphon and occasionally on Asperococcus, and the small sporophytes occurred in the same zone on abiotic substrata. However, we also recorded the species once on Bifurcaria in the low intertidal, and on an exposed shore, where E. crouaniorum was the only intertidal Ectocarpus, thalli were also found on Corallina in a mid-intertidal pool. Macrothalli were only present from the end of March to the end of June. Ectocarpus siliculosus occurred from mid-intertidal pools down to the upper subtidal, on Sargassum, Ulva, Porphyra, Gracilaria, Saccharina and Himanthalia, within a seagrass bed and on old Zostera leaves. A previously isolated strain of E. siliculosus from Roscoff (CCAP1310/177) was dredged from 10m depth (Müller and Eichenberger 1995). Macrothalli of E. siliculosus were not only present in spring but also collected in August, September and November. Admittedly, individual Ectocarpus thalli may be difficult to identify in spring, and given the morphological similarity between E. crouaniorum and small E. siliculosus, these two may be regarded as cryptic species. Occasionally, E. crouaniorum may form viable hybrids with E. siliculosus. This occurred in one out of our 11 crossing experiments involving the two species but in the hybrids meiosis was stopped at an early stage, similar to the abortive unilocular sporangia described in crosses 
between Ectocarpus strains from geographically distant origins (Müller 1988; Stache 1989). One out of 26 genotyped field thalli was a putative field hybrid showing a double band corresponding to ITS1 lengths of both E. crouaniorum and E. siliculosus. Judging from their rarity in the field the hybrids do not seem to show increased hybrid vigour (heterosis). Viable hybrids between closely related seaweed species are not uncommon (e.g. in Fucus, Coyer et al. 2002). More extensive sampling will be required to estimate the extent of hybridisation between E. crouaniorum and E. siliculosus in the field. E. fasciculatus is even more separated from E. crouaniorum on the shore, as it was found in the lowermost intertidal and in the subtidal, where it was regularly encountered on Laminaria, Saccharina, Saccorhiza, Himanthalia and green leaves of Zostera marina. It could be collected all year round and was abundant in late summer and autumn. Its different morphology usually allows distinction from E. siliculosus, which may occur in the same habitat, as well as from E. crouaniorum.

Using the ITS1 sequences of E. crouaniorum as a barcode we found that strains of Ectocarpus collected by Dieter Müller in 1976 at the Isle of Man (Müller 1977) and in 1990 at the Aran Islands, Ireland, belonged to the same species. Both had been collected in intertidal pools, the Aran Island isolate was even epiphytic on Scytosiphon (cf. strain information on www.ccap.ac.uk). This shows that E. crouaniorum also occurs in the British Isles. Batters (1902), who recognised the species, mentioned records from Cornwall, Essex and SW Scotland but considered it to be rare. Müller (1977) crossed gametophytes from the Isle of Man with Mediterranean E. siliculosus and regarded the observed zygotic compatibility as proof of conspecificity. However, apparently no attempts was made to raise the zygotes.

The Manx strains of E. crouaniorum collected by Dieter Müller survived up to $28^{\circ} \mathrm{C}$ in ecophysiological studies on temperature requirements of E. siliculosus (Bolton 1983). This result 
coincides well with the occurrence of E. crouaniorum in upper intertidal pools, which may warm up during low tide on sunny days. According to the phylogenetic tree of Dieter Müller's worldwide Ectocarpus strain collection (Stache-Crain et al. 1997), E. crouaniorum belongs to branch 2 containing also isolates from North Carolina, Florida, Texas and the Canary Islands, i.e. localities with elevated summer sea surface temperatures. Other strains in that branch are from Chile, South Africa, Helgoland and from a German river influenced by salt mining. It appears likely that $E$. crouaniorum is widely distributed. Müller and Eichenberger $(1994,1995)$ introduced DGTA content to distinguish species in Ectocarpus. This was corroborated but modified in Stache-Crain et al. (1997) who showed that both E. fasciculatus (branch 5b) and members of branch 2abc (E. crouaniorum) contained DGTA. Of the two gametophytes of E. crouaniorum from the Isle of Man, however, only one contained DGTA, and the strain from Aran Island only traces. In addition, a case of lack of DGTA in E. fasciculatus (Müller and Eichenberger 1997) showed that the value of DGTA for chemotaxonomy of Ectocarpus is limited.

A single isolate of Ectocarpus in our collection did not belong to E. siliculosus, E. fasciculatus or E. crouaniorum; sequences showed that it is more closely related to E. fasciculatus than to the two other taxa but that it belongs to a lineage (branch 5a in Stache-Crain et al. 1997) which is separated from Roscovite E. fasciculatus (branch $5 b$ ). Our material, which originated from a minute Ectocarpus thallus epiphytic on an intertidal Scytosiphon at Cherbourg, Normandy, was genetically similar to an isolate collected by Dieter Müller at Hvidøre near Copenhagen in June 1979. According to his unpublished notes, field thalli were up to $40 \mathrm{~cm}$ in length and bore plurilocular and unilocular sporangia. He isolated male and female gametophytes and both were capable of plasmogamy with strains of E. siliculosus from Naples. Müller concluded that the 
Copenhagen isolate belonged to E. siliculosus, which is contradicted by the sequences. So far we are unable to provide a name for this entity.

Our phylogenetic analyses were based on a more limited taxon set than in Stache-Crain et al. (1997), but two additional mitochondrial markers (953bp) provided more resolution. Our results confirmed that within Ectocarpus, two main branches, corresponding to the sections fasciculati and siliculosi, can be recognised. However, the trees suggest there are at least five different lineages within Ectocarpus separated by large genetic distances. E. crouaniorum clustered within the siliculosi but was well separated from genuine E. siliculosus. Phylogenetic analyses of the entire diversity of Ectocarpus from world-wide collections may show whether other lineages within the two sections also merit recognition as separate species.

Our study was restricted to Ectocarpus from intertidal habitats. The sublittoral offers a diversity of additional habitats and we do not exclude the possibility that more entities of Ectocarpus may be present in that zone. For instance, we have not collected any Kuckuckia although the genus had been reported in our study area by Cardinal (1964).

In conclusion, our results suggest that species diversity in Ectocarpus is higher than assumed during the last four decades but that morphology is not sufficient to distinguish all species. In future studies employing Ectocarpus care should be taken that the exact origin, habitat and collection date of the material are recorded, and that the identity is established without doubt, best by using molecular markers.

\section{ACKNOWLEDGEMENTS}

We thank Dieter G. Müller for providing strains of Ectocarpus and Kuckuckia and sharing unpublished data, and Willem Prud'homme van Reine for advice concerning the Ectocarpus taxa described by Kützing. Collections at Sites 6 and 7 were undertaken in the frame of French- 
Korean scientific cooperation (PAI STAR 2005/2006 project 11836NH to AFP and SMB). The study was started when the first author was working at the Station Biologique de Roscoff, and it was finished in the laboratory of the Marine Biological Association of the United Kingdom, Plymouth, thanks to a Ray Lankester Investigatorship for AFP. 


\section{REFERENCES}

Altschul, S. F., Madden, T. L., Schaffer, A. A., Zhang, J., Zhang, Z., Miller, W., and Lipman, D. J. 1997. Gapped BLAST and PSI-BLAST: a new generation of protein database search programs. Nucleic Acids Res. 25: 3389-3402.

Batters, E. A. L. 1902. A catalogue of the British marine algae. J. Botany 40 (suppl.): 1-107.

Berthold, G. 1881. Die geschlechtliche Fortpflanzung der eigentlichen Phaeosporeen. Mitt. Zool. Stat. Neapel 2: 401-413.

Bolton, J. J. 1983. Ecoclinal variation in Ectocarpus siliculosus (Phaeophyceae) with respect to temperature growth optima and survival limits. Marine Biol. 73: 131-138.

Cardinal, A. 1964. Étude sur les Ectocarpacées de la Manche. Nova Hedwigia, Beihefte 15: 1-86.

Charrier, B., Coelho, S. M., Le Bail, A., Tonon, T., Michel, G., Potin, P., Kloareg, B., Boyen, C., Peters, A. F. and Cock, J. M. 2008. Development and physiology of the brown alga Ectocarpus siliculosus: two centuries of research. New Phytologist 177: 319-332.

Coelho, S. M., Peters, A. F., Charrier, B., Roze, D., Destombe, C., Valéro, M. and Cock, J. M. 2007. Complex life cycles of multicellular eukaryotes: new approaches based on the use of model organisms. Gene 406: 152-170.

Coyer, J. A., Peters, A. F., Hoarau, G., Stam, W. T. and Olsen, J. L. 2002. Hybridization of the marine seaweeds, Fucus serratus and Fucus evanescens (Heterokontophyta: Phaeophyceae) in a 100year-old zone of secondary contact. Proc. R. Soc. Lond. B. 269:1829-1834.

Crouan, P. L. and Crouan, H. M. 1852. Algues marines du Finistère. Brest.

Gallardo, T. 1992. Nomenclatural notes on some Mediterranean algae, I: Phaeophyceae. Taxon 41: 324-325. 
Guiry, M. D. and Guiry, G. M. 2009. AlgaeBase. World-wide electronic publication, National University of Ireland, Galway. http://www.algaebase.org; searched on 24 August 2009. Hamel, G. 1931-1939. Phéophycées de France. Paris.

Hamel, G. 1939. Sur la classification des Ectocarpales. Botaniska Notiser 1939: 65-70.

Huelsenbeck, J. P. and Ronquist, F. 2001. MRBAYES: Bayesian inference of phylogeny. Bioinformatics 17: 754-755.

Kim, H. S. and Lee, I. K. 1992. Morphotaxonomic studies on the Korean Ectocarpaceae (Phaeophyta). I. Genus Ectocarpus Lyngbye. Korean J. Phycol. 7: 225-242.

Kornmann, P. 1956. Über die Entwicklung einer Ectocarpus confervoides-Form. Pub. sta. zool. Napoli 28: $32-43$.

Kornmann, P. and Sahling, P.-H. 1977. Meeresalgen von Helgoland. Benthische Grün-, Braun- und Rotalgen. Helgoländer wiss. Meeresunters. 29: 1-289.

Kuckuck, P. 1912. Beiträge zur Kenntnis der Meeresalgen. 11. Zur Fortpflanzung der Phaeosporeen. Wissenschaftl. Meeresunters., Abt. Helgoland 5: 155-184.

Kuckuck, P. 1958. Ectocarpaceen-Studien. V. Kuckuckia, Feldmannia. Helgoländer wiss. Meeresunters. 6: 171-192.

Kützing, F. T. 1843. Phycologia generalis. Leipzig.

Kützing, F. T. 1845. Phycologia germanica. Nordhausen.

Kützing, F. T. 1849. Species algarum. Leipzig.

Kützing, F. T. 1855. Tabulae phycologicae 5. Nordhausen

Kützing, F. T. 1860. Tabulae phycologicae 10. Nordhausen.

Le Corguillé, G., Pearson, G., Valente, M., Viegas, C., Gschloessl, B., Corre, E., Bailly, X, Peters, A. F., Jubin, C., Vacherie, B., Cock, J. M. and Leblanc, C. 2010. Plastid genomes of two brown 
algae, Ectocarpus siliculosus and Fucus vesiculosus: further insights on the evolution of red-algal derived plastids. BMC Evolutionary Biology $\mathbf{x x}$ : xx-xx [accepted manuscript].

Le Jolis, A. 1863. Liste des algues marines de Cherbourg. J.B. Bailliere et Fils, Paris.

Müller, D. G. 1964. Life-cycle of Ectocarpus siliculosus from Naples, Italy. Nature 203: 1402.

Müller, D. G. 1966. Untersuchungen zur Entwicklungsgeschichte der Braunalge Ectocarpus siliculosus aus Neapel. Planta 68: 57-68.

Müller, D. G. 1967. Generationswechsel, Kernphasenwechsel und Sexualität der Braunalge Ectocarpus siliculosus im Kulturversuch. Planta 75: 39-54.

Müller, D. G. 1972. Life cycle of the brown alga Ectocarpus fasciculatus var. refractus (Kütz.) Ardis. (Phaeophyceae, Ectocarpales) in culture. Phycologia 11: 11-13.

Müller, D. G. 1976. Sexual isolation between a European and an American population of Ectocarpus siliculosus (Phaeophyta). J. Phycol. 12: 252-254.

Müller, D. G. 1977. Sexual reproduction in British Ectocarpus siliculosus (Phaeophyta). Br. phycol. J. 12: $131-136$.

Müller, D. G. 1979. Genetic affinity of Ectocarpus siliculosus (Dillw.) Lyngb. from the Mediterranean, North Atlantic and Australia. Phycologia 18: 312-318.

Müller, D. G. 1988. Studies on sexual compatibility between Ectocarpus siliculosus (Phaeophyceae) from Chile and the Mediterranean Sea. Helgoländer Meeresunters. 42: 469-476.

Müller, D. G. 1991. Mendelian segregation of a virus genome during host meiosis in the marine brown alga Ectocarpus siliculosus. J. Plant Physiol. 137: 739-743.

Müller, D. G. and Eichenberger, W. 1994. Betaine lipid content and species delimitation in Ectocarpus, Feldmannia and Hincksia (Ectocarpales, Phaeophyceae). Eur. J. Phycol. 29: 219-25. 
Müller, D. G. and Eichenberger, W. 1995. Crossing experiments, lipid composition, and the species concept in Ectocarpus siliculosus and E. fasciculatus (Phaeophyceae, Ectocarpales). J. Phycol. 31: $173-176$.

Müller, D. G. and Eichenberger, W. 1997. Mendelian genetics in brown algae: inheritance of a lipid defect mutation and sex alleles in Ectocarpus fasciculatus (Ectocarpales, Phaeophyceae). Phycologia 36: 79-81.

Müller, D. G. and Kawai, H. 1991. Sexual reproduction of Ectocarpus siliculosus (Ectocarpales, Phaeophyceae) in Japan. Jpn. J. Phycol. 39: 151-155.

Ni-Ni-Win, Hanyuda, T., Arai, S., Uchimura, M., Abbott, I. A. and Kawai, H. 2008. Three new records of Padina in Japan based on morphological and molecular markers. Phycol. Res. 56: 288-300. [cited in Table 3]

Papenfuss, G. F. 1935. Alternation of generations in Ectocarpus siliculosus. Bot. Gazette 96: 421-446.

Pedersen, P. M. 1989. Studies on Kuckuckia spinosa (Fucophyceae, Sorocarpaceae): life history, temperature gradient experiments, and synonymy. Nordic J. Bot. 9: 443-447.

Peters, A. F. and Ramírez, M. E. 2001. Molecular phylogeny of small brown algae, with special reference to the systematic position of Caepidium antarcticum (Adenocystaceae, Ectocarpales). Cryptogamie, Algol. 22: 187-200.

Peters, A. F., Marie, D., Scornet, D., Kloareg, B. and Cock, J. M. 2004a. Proposal of Ectocarpus siliculosus as a model organism for brown algal genetics and genomics. J. Phycol. 40: 10791088.

Peters, A. F., Scornet, D., Müller, D. G., Kloareg, B. and Cock, J. M. 2004b. Inheritance of organelles in artificial hybrids of the isogamous multicellular chromist alga Ectocarpus siliculosus (Phaeophyceae). Eur. J. Phycol. 39: 235-242. 
Peters, A. F., Scornet, D., Ratin, M., Charrier, B., Monnier, A., Merrien, Y., Corre, E., Coelho, S. M. and Cock, J. M. 2008. Life-cycle-generation-specific developmental processes are modified in the immediate upright mutant of the brown alga Ectocarpus siliculosus. Development 135: 15031512.

Posada, D. and Crandall, K. A. 1998. MODELTEST: testing the model of DNA substitution. Bioinformatics 14: 817-818.

Prud'homme van Reine, W. F. \& C. den Hartog. 1973. The types of Kützing's new species of Corticularia, Ectocarpus and Spongonema. Taxon 22: 93-96.

Ricker, R. W. 1987. Taxonomy and Biogeography of Macquarie Island Seaweeds. British Museum (Natural History), London.

Russell, G. 1966. The genus Ectocarpus in Britain. I. The attached forms. J. mar. biol. Ass. UK. 46: 267-294.

Russell, G. 1967. The genus Ectocarpus in Britain. II. The free-living forms. J. mar. biol. Ass. UK. 47: 233-250.

Santelices, B. 1989. Algas Marinas de Chile. Distribución, Ecología, Utilización, Diversidad. Editiones Universidad Católica de Chile.

Stache, B. 1989. Sexual compatibility and species concept in Ectocarpus siliculosus (Ectocarpales, Phaeophyceae) from Italy, North Carolina, Chile, and New Zealand. In Garbary, D. J. and South, R. G. (Eds) Evolutionary Biogeography of the Marine Algae of the North Atlantic. Springer, Berlin, pp. 173-186.

Stache, B. 1993. Kreuzungsexperimente bei Braunalgen. Vergleich von Lokalpopulationen des Kosmopoliten Ectocarpus siliculosus. Hartung-Gorre, Konstanz. 
Stache-Crain, B., Müller, D. G. and Goff, L. J. 1997. Molecular systematics of Ectocarpus and Kuckuckia (Ectocarpales, Phaeophyceae) inferred from phylogenetic analysis of nuclear and plastid-encoded DNA sequences. J. Phycol. 33: 152-168.

Starr, R. C. and Zeikus, J. A. 1993. UTEX-The culture collection of algae at the University of Texas at Austin. J. Phycol. 29 (suppl.): 1-106.

Stegenga, H., Bolton, J. J. and Anderson, R. J. 1997. Seaweeds of the South African West coast. Bolus Herbarium, Cape Town.

Swofford, D.L. 2002. PAUP: phylogenetic analysis using parsimony, version 4.0b10. Sinauer Associates, Sunderland.

Valentin, K. and Zetsche, K. 1990. Rubisco genes indicate a close phylogenetic relation between the plastids of Chromophyta and Rhodophyta. Plant Mol. Biol. 15: 575-584.

van den Hoek, C. 1975. Phytogeographic provinces along the coasts of the Northern Atlantic Ocean. Phycologia 14: 317-330.

White, T. J., Bruns, T. D., Lee, S. B. and Taylor, J. W. 1990. Analysis of phylogenetic relationships by amplification and direct sequencing of ribosomal genes. In Innis M. A., Geleand D.H., Sninsky J. J. and White T. J. (Eds.) PCR protocols. Academic Press, New York, pp. 315-322. [cited in Table 3] 


\section{FIGURE LEGENDS}

Fig. 1. Collecting sites of Ectocarpus in NW France, Western Europe. See Table 1 for details.

Figs 2-4. Ectocarpus spp. at Roscoff, Brittany. Herbarium specimens, same scale.

2. Gametophytes of E. crouaniorum epiphytic on the erect phase of Scytosiphon. 21 March 2004, high intertidal run-off. 3. A thallus of E. siliculosus, epiphytic on Ulva (host removed). 1 July 2003, mid-intertidal pool. 4. Thalli of E. fasciculatus, epiphytic on Zostera. 1 July 2003, drift material.

Figs 5-7. ITS1 length genotypes in Ectocarpus from NW France. DNA bands after PCR with primers AFP4LF and 5.8S1R amplifying ITS1 + 340bp flanking sequences. Agarose gel electrophoresis, length standards (from below) 400, 600, 800, 1000, 1500 bp. fas $=$ E. fasciculatus, sp. = genotype with unknown name, sil $=$ E. siliculosus, cro $=$ E. crouaniorum . 5. The four different ITS1 length genotypes found in the present study. 6. Example of genotyping: 12 isolates from Site 5, including 2 fas, 9 sil and 1 cro. Lane 8 (counted from left side $)=$ length standard, lane $14=$ negative control. $\quad$ 7. ITS1 of Ectocarpus hybrids. HL $=$ hybrid produced in laboratory by crossing cro female $\mathrm{x}$ sil male. $\mathrm{HF}=$ putative hybrid isolated from field. The central of the triple bands in the hybrids is a PCR artefact due to amplification of both sequences in the same tube.

Figs 8-13. Ectocarpus at Roscoff. 8. E. crouaniorum, field gametophyte, plurilocular, 17 March 2004. 9. Result of crossing experiment between a male E. crouaniorum and a female E. siliculosus, six days after start of experiment; left, degenerating hybrid germling, right, 
germling from settled gamete, developing normally. 10. Sporophyte from a cross female E. crouaniorum $\mathrm{x}$ male E. siliculosus. Initial stage of meiosporangium; sporangia did not develop beyond this stage. 11. Similar developmental stage in culture of a sporophyte of E. crouaniorum; two hemispherical unilocular sporangium mother cells are visible. 12. Mature unilocular sporangium in the same sporophyte as in Fig. 11. 13. Partly released unilocular sporangium in a field sporophyte of E. crouaniorum, 26 March 2004. Same scale in 10-13.

Fig. 14. Maximum likelihood tree (-ln $L=4764.7661)$ of 13 Ectocarpus and two Kuckuckia isolates based on combined sequences from ITS1 + ITS2 + Rubisco spacer region + cox3 + rps 14 . ML bootstrap (left) and Bayesian posterior probability (right) values are shown above the branches. The three main clades (from below) are Kuckuckia (outgroup), Ectocarpus section fasciculati and Ectocarpus section siliculosi. Within the latter, E. crouaniorum (above) forms a clade separated from genuine E. siliculosus (below). Affiliation of the strain from New Zealand, which was referred to as E. siliculosus in Müller (1991) and Peters et al. (2004b), is uncertain as it does not cluster with significant support with E. crouaniorum or genuine E. siliculosus.

Figs 15-16. Sporophyte of E. crouaniorum. 14. Thalli forming a felt on old Patella shell. Site 1, 15 April 2007. Dark spots on left side of shell are brown crusts, possibly the prostrate phase of Scytosiphon. 15. Plurilocular (above) and young unilocular sporangium (below). Isolate from Site 3, reproductive organs formed in culture. 